\title{
AyurloG
}

National Journal of Research in Ayurved Science

http://www.ayurlog.com

Nov- 2020 | Volume 08 ${ }^{\text {th }} \mid$ Issue: $6^{\text {th }}$

ISSN: 2320-7329

\section{To Study the Shulaghna effect of Shatapushpa and Shatavari Siddha Taila Matra Basti in Management of Udavarta Yonivyapad W.S.R. to Dysmenorrhoea.}

Piyush M. Purohit*1 ${ }^{1}$, Nilesh N. Wagh ${ }^{2}$, Vishnu B. Giri ${ }^{3}$

1. Assistant Professor, Strirog And Prasuti Tantra

2. Associate Professor, Panchakarma Department

3. Assistant Professor, Shalya Tantra Department

SRC Ayurveda college Chikhli, District Buldhana, Maharashtra

*Corresponding author: 9665142074; Email ID: piyushpurohit22@ gmail.com

\begin{abstract}
:-
Udavarta Yonivyapada is a disorder, with difficult menstruation, as a result of morbid vata dosha, which affects the women in their reproductive age. In mithyachara, the diet and mode of life which vitiate vata is to be considered. The diet which is ruksha, sheeta, shushka vitiates vata. Similarly they may lead to nutritional deficiency. In both groups patients having followed up of for 3 cycles it was observed that Matra basti of Shatpushpa Shatavari siddha tail reduces and cures the symptom Vedana significantly. Mann Whitney test applied to effect of therapy on symptoms of both groups was found highly significant, in Group-A as compared to Group-B except in Malavashtambha.It shows that, Shatpushpa Shatavari siddha tail acts effectively in Udavarta yonivyapada.
\end{abstract}

\section{Keywords:-}

Shulaghna, Shatapushpa, Shatavari, Matra

Basti, Udavarta Yonivyapad,

Dysmenorrhoea.

\section{Introduction:}

Today many women are suffering from sashul raja pravrutti. The severity of this pain is to such an extent that it interferes with their routine life and they are not able to do the routine work and have to take rest.

Raja pravrutti is regulated by Apana vayu since it plays a vital role in dharan and nishkraman of raja, vitiation of Apana vayu therefore leads to sashul raja pravrutti ${ }^{(5)}$

Udavarta yonivyapada is one of the yonivyapada where morbid vata obliterates the Artava and expel it with difficulty. 
Painful menstruation is the cardinal symptom in this condition and it is mostly seen that in common practise at around 50\% to $60 \%$ of women suffer from this. It is considered as an extensive personal and public health problem for woman.

Basti karma and sanshodhan chikitsa have been described in granthas for Udavarta yonivyapada. ${ }^{(5)}$

Considering these factors an attempt has been made to study scientifically and statistically a formulation which comprehensively give relief to the symptom pain seen in Udavarta yonivyapada.

The formulation selected is "Shatpushpa Shatavari siddha tail matra basti in Udavarta yonivyapada”. (8)

\section{Aims and objectives}

\section{Aim:-}

To study the shulghna effect of Shatpushpa and Shatavari siddha tail matra basti in management of udavarta yonivyapad w.s.r. to Dysmenorrhoea.

\section{Objective:}

- To study the shulghna effect of Shatpushpa and Shatavari siddha tail on udavarta yonivyapad.

- The study the changes in vedana, vedanakalavadhi, rajastrav, in udavarta yonivyapad.

- To study the detailed literature about Udavarta Yonivyapada

- To study the detailed literature about contents of drug and their effect.
- To study the efficacy of Matra basti of Shatpushpa and Shatavari siddha tail in Udavarta yonivyapada.

- To provide most effective drug with minimal side effects.

- To study the patient 5 days $(+/-2$ days) prior to EMD for 3 months and follow up 7 days prior to the expected menstrual date for 3 months.

Nidan

- Vegavrodha

- Less hours of sleeping

- Ruksha, Laghu, Sheeta ahar

- Anxiety due to lack of reproductive Knowledge

- Daurbalya

- Excessive Travelling

- Ativyayam.

- Excessive Physical work

- Dieting (wt. reduction)

- Excessive mental stress

\section{SAMPRAPTI GHATAK}

- Hetu :-Mala,Mutradi vegavrodh, Laghu, Ruksha, Sheeta ahar.

- Dosha :-Vata. (Apana vayu) = Dushya: - Rasa, Rakta,Mansa.

- Srotas :-Artavaha srotas

- Srotodushti prakar :-Vimarga-gaman

- Udbhava Sthana :-Pakwashaya.

- Vyakta Sthana :-Garbhashaya

- Rupa :- Vimukta tatkshanam Sukham Phenil raja Vedana (Garbhashaya) Yoni Prapidan Ubhay pada shola Angamarda Katishoola Malavashtambha 


\section{Upadrava and sadhya asadhyatwa:}

Even though specific upadravasare not mentioned, those for Yonivyapadacan be considered

Pradara, gulma, arsha, vandhyatwa, are some of the Updravasseen in this vyapada. (3)

Udavarta yonivyapadais considered as Sadhya if vata is controlled then the disease can be cured. ${ }^{(5)}$

\section{Chikitsa of Udavarta Yonivyapada:}

- To reduce pain - Pain relieving preparations.

- To reduce rukshataand kharata- Oil preparation for external and internal use.

- To bring Apana vayu in its normal gati - Mild Laxatives and Basti chikitsa is to be given. ${ }^{(5)}$

Basti karma and sanshodhanchikitsa have been described in granthas for Udavarta yonivyapada. ${ }^{(6)}$ Considering these factors an attempt has been made to study scientifically and statistically a formulation which comprehensively give relief to the symptom pain seen in Udavarta yonivyapada. The formulation selected is Shatpushpa Shatavarisiddha tail matra basti in Udavarta yonivyapada.

\section{Dysmenorrhoea.}

The Cardinal symptom is difficulty in expelling the raja. Although all Acharya's agree with this Charakahas mentioned the relief of symptom once the flow starts, which denotes the primary dysmenorrhoea.
Menstruation is a normal physiological process, if accompanied with pain is called as dysmenorrhoea. ${ }^{(9)}$

Dysmenorrhoea refers to the chronic, cyclic pain or discomfort in the pelvic region during a menstrual period. ${ }^{(9)}$

Dysmenorrhoea means painful menstruation and is classified as primary (from the onset of menstruation) or secondary (due to some physical cause and usually of later onset). ${ }^{(9)}$

The uterus is a muscle. Like all muscles, it contracts and relaxes. Most uterine contractions are never noticed, but strong ones are painful. During strong contractions, the uterus may contract too strongly or too frequently, causing the blood supply to the uterus to be temporarily cut off. This deprives the muscle of oxygen, causing pain. This pain may be located in the abdomen or the back. ${ }^{(9)}$

Who is at risk for Dysmenorrhoea.

- Age :- $\quad[<20-30$ yrs]

- Thin Built $:-[\mathrm{BMI}<20]$

- Overweight

- Early menarche : - [<12 yrs $]$

- Longer cycles / Duration of bleeding

- Irregular or heavy menstrual flow

- Pelvic inflammatory disease

- Nulliparity

- Positive family history

- Smoking and Stress. 
TREATMENT OF DYSMENORRHOEA

- Rest

- Heating pad to the lower abdomen or back

- Proper nutrition

- Aerobic exercise

- Meditation.

- Nutrition therapy includes a wellbalanced diet.

- Adequate intake of calcium (500mg. per day)each day.

- Vitamin E

- Medication for dysmenorrhoea may involve two complementary strategies

- Decreasing prostaglandin production (NSAIDS) and
- Hormonal alteration.

Drugs: To prepare the siddha tail the contents required are as follows,

Shatpushpa Shatavari kwath Kalk extracted from above preparation. ${ }^{(7)}$

KALKA

OIL

KWATH

(1 PART)

(4 PARTS)

\section{(16 PARTS)}

Materials:-

- $60 \mathrm{ML}$ syringe

- simple rubber catheter

- Gloves.

\section{OBSERVATION CRITERIA:-}

\begin{tabular}{|l|l|c|}
\hline Observation & \multicolumn{1}{|c|}{ Criteria } & Result \\
\hline \multirow{4}{*}{$\begin{array}{l}\text { 1.Vedana } \text { Shoola) } \\
\text { 2.Vedana }\end{array}$} & No pain & 0 \\
\cline { 2 - 3 } kalavadhi & Mild (having pain, can do routine work) & 1 \\
\cline { 2 - 3 } & Moderate(can do work in two intermittent pain) & 2 \\
\cline { 2 - 3 } & Severe (can't work, bed ridden) & 3 \\
\hline \multirow{5}{*}{ 3.Rajah strava } & No Pain & 1 \\
\cline { 2 - 3 } & Mild(pain from 1day before menses) & 2 \\
\cline { 2 - 3 } & Moderate(pain from 2days before menses) & 3 \\
\cline { 2 - 3 } & Severe(>3days before menses) & 0 \\
\cline { 2 - 3 } & Normal & 1 \\
\cline { 2 - 3 } & Mild(2-3 pads/24hrs) & 2 \\
\cline { 2 - 3 } & Moderate(3-5 pads/24hrs) & 3 \\
\cline { 2 - 3 } & Severe(>5pads/24hrs) & \multirow{2}{*}{1} \\
\hline
\end{tabular}




\section{Statistical Analysis:-}

The statistical analysis of the effect of therapy on symptoms of Udavarta yonivyapada by Wilcoxon sign rank test and Mann Whitney test. ${ }^{(10)}$

By applying Wilcoxon sign rank test on all the symptoms in both the groups, the $\mathrm{P}<0.001$, means it is significant.

By applying Mann - Whiteney test on all the symptoms while comparison, the $\mathrm{P}<0.001$, means it is significant.

In the present study, according collected data, it is observed that both the drugs i.e. Shatavari Shatpushpa Tail and Mefanamic Acid have provided significant relief in the symptoms of Udavarta Yonivyapad. But Shatavari Shatpushpa Tail has provided relatively better relief than Mefanamic Acid in all symptoms of Udavarta Yonivyapad.

\section{Discussion:-}

Discussion is the important step which helps in understanding the subject and it guides to make a conclusion.

For the study of efficacy of Shatavari Shatpushpa siddha tail matra basti, in management of Udavarta yonivyapada, 60 patients were selected. They were examined, observed for the signs \& symptoms. The results and observations after study were completed and are mentioned earlier and discussed as follows-

\section{Mode of action of drug:}

Drugs are Tridoshagnha and specially Vatagnha, it specifically acts on Vata dosha and are said to be best vatagnha dravya's. They also act as Artava Janan which cure the symptoms as vandyatva. It acts as vatanulomak cures vegavrodh and acts for raja strav.

Drug has Ushna veerya has Deepana, Pachan, Virechan and Vilayan property which softens and liquefies the morbid Vata dosha which are ultimately expelled out due to Anulomak karma.

\section{Conclusion:}

Udavarta Yonivyapada is a disorder, with difficult menstruation, as a result of morbid vata dosha, which affects the women in their reproductive age.

In mithyachara, the diet and mode of life which vitiate vata is to be considered. The dief which is ruksha, sheeta, shushka vitiates vata. Similarly they may lead to nutritional deficiency.

Anxiety, depression and lack of reproductive knowledge in puberty age are been associated with udavarta yonivyapada.

Stress and exertion which are the result of present life style, is the risk factor in udavarta yonivyapada.

Udavarta is a sadhya vyadhi. Vata is to be controlled in this with appropriate medicine.

The condition udavarta resembles the description of almost all types of dysmenorrhoea.

On the basis of the symptom of immediate relief of pain following discharge of menstrual blood, it appears to be nearer to spasmodic or true dysmenorrhoea. 
In both groups patients having followed up of for 3 cycles it was observed that Matra basti of Shatpushpa Shatavari siddha tail reduces and cures the symptom Vedana significantly.

Psychological factors like stress, anxiety were observed as causative factors for udavarta yonivyapada. Percentage of udavarta yonivyapada was observed more in VataPittaja prakriti Unmarried, Nulliparous, Students \&working women's.

Socio-economic status wise, religion wise, there was no significant conclusion drawn.

Mann Whitney test applied to effect of therapy on symptoms of both groups was found highly significant, in Group-A as compared to Group-B except in Malavashtambha.

It shows that, Shatpushpa Shatavari siddha tail acts effectively in Udavarta yonivyapada.

\section{References:-}

1. Ashtang hriday, Reprint 2011, Vd. Yadunandan
Chaukhamba Prakashan, Kaviraj Atridevji.

2. Ashtang sangrah, Reprint 2005, Vd. Yadunandan Upadhyayji, Nirnay Prakashan, Kaviraj Atridevji.

3. Rog nidan vikritivigyan, 2007, Dr. Jain, Chaukhamba Prakashan, Dr. Jain.

4. BhavPrakash Nighantu, 2004, Dr. Gangasahay pandey, Chaukhamba Prashan, Bhavprakashji.

5. Charak Samhita, 1997 Reprint, Dr. Deshpande, Chaukhamba Prashan, Brahmanandji Tripath.

6. Sushrut samhita, 2003, Ambikadutt Shashtri, Chaukhamba Prashan, A.Shashtriji.

7. Dravya Gun vigyan, 2007, Vd. Gogate, Vaidyamitra Prakashan.

8. Kashyap samhita, 2005, Pandit Sharma, Chaukhamba Prashan, Vruddha Jivak.

9. Text book of Gynaecology, 1994, Hiralal Konar, Jaypee Brothers, Hiralal Konar.

10. Textbook of Pathology, 6th Edition, 2005, Ivan Damjanov, Jaypee Brothers, Harsh Mohan

Conflict of Interest: Non

Source of funding: Nil

Cite this article:

To Study the Shulaghna effect of Shatapushpa and Shatavari Siddha Taila Matra Basti

in Management of Udavarta Yonivyapad W.S.R. to Dysmenorrhoea.

Piyush M. Purohit, Nilesh N. Wagh, Vishnu B. Giri

Ayurlog: National Journal of Research in Ayurved Science- 2020; (8) (6):01-06 